DOI: $10.4067 /$ S0718-16202014000300011

\title{
The importance of weeds as melliferous flora in central Chile
}

\author{
Lissette Grimau, Miguel Gómez, Rodrigo Figueroa, Rodrigo Pizarro, \\ Gabriel Núñez, and Gloria Montenegro \\ Departamento de Ciencias Vegetales, Facultad de Agronomía e Ingeniería Forestal, Pontificia Universidad \\ Católica de Chile. Avenida Vicuña Mackenna 4860, Macul, Santiago, Chile.
}

\begin{abstract}
L. Grimau, M. Gómez, R. Figueroa, R. Pizarro, G. Núñez, and G. Montenegro. 2014. The importance of weeds as melliferous flora in central Chile. Cien. Inv. Agr. 41(3):387394. The use of native flora by Apis mellifera $\mathrm{L}$. in Chile has been demonstrated in many studies; however, certain species that are viewed as weeds contribute extensively to the floral composition of honey. A total of 92 honey samples from the Libertador General Bernardo O'Higgins region in Chile were analyzed to determine which weeds are most important in honey production and which are most preferred by melliferous bees. Their relative contributions to the pollen fraction of each honey sample were also determined using melissopalynological tests in accordance with Chilean regulation (NCh2981.Of2005; Ministerio de Agricultura. 2006) to evaluate the botanical origins of the honey samples. Species considered weeds were classified according to their importance in Chilean crops, as proposed by Matthei (1995), based on the classification system by Holm (1979). These authors categorize weeds on a scale that ranges from "very serious", if they potentially cause significant crop loss, to "occasionally present as weeds" if they are part of the national flora. A total of 19 weeds were identified at the species level from the pollen types found, and five weeds were identified at the genus level. The weeds were classified as contributing very frequently, frequently, rarely and occasionally to honey using the methodology described by Louveaux et al. (1970) for determining the frequency with which plant species contribute to honey based on the corresponding pollen types found in honey. Overall, $74 \%$ of the weeds used by Apis mellifera were European, and $53 \%$ of the weeds had perennial life cycles. The families that contributed the most to honey production were Fabaceae, Asteraceae and Brassicaceae. The importance of species viewed as weeds in the production of Chilean honey is discussed.
\end{abstract}

Key words: Apis mellifera L., Central Zone, Chile, Fabaceae, weeds.

\section{Introduction}

Only certain vegetal species are of interest for beekeeping, as the production and support of the hive depend on the amount of nectar produced

Received June 18, 2014. Accepted November 4, 2014. Corresponding author: 1jgrimau@uc.cl by flowers and the abundance of melliferous vegetation near the apiary. Estimates indicate that melliferous bees forage over an area with an average radius of $5.5 \mathrm{~km}$ around the apiary (Beekman and Ratnieks, 2000). On the other hand, melliferous bees (Apis mellifera L.) are selective in terms of the flowers that they visit and use only a portion of the available flora, as only 
certain flowers represent a favorably energetic and harmless resource; moreover, the shapes of certain flowers make them difficult for bees to exploit (Duffield et al., 1993; De Sá Otero et al., 2004; Martin, 2004; Montenegro et al., 2010). Although weeds can be one of the most harmful factors in crop production, with losses that are approximately $34 \%$ greater than the potential damage caused by insects and pathogens (Oerke, 2006), it is also noteworthy that certain weeds may be useful in honey production by $\mathrm{A}$. mellifera. Invading species in agricultural areas of South Central Chile, e.g., Rubus ulmifolius and Ulex europaeus, have been reported to be used by melliferous bees during the period coinciding with the most intense activity in the hive. Both of these weeds are perennials and were introduced to Chile in 1860 by German colonists (Groves and di Castri, 1991). A regional project is being developed in the region of Libertador General Bernardo O'Higgins (FIC - R code ID 30126395-0) to analyze the honeys produced in the region to determine their botanical origins and biological properties. This information may help beekeepers to differentiate their export honeys and thereby add value. In this context, analyses of the botanical origin of 92 honey samples from the region that was studied detected the presence of species considered weeds based on the pollen residues in the honey samples. Thus, weeds used by melliferous bees as a nectar source can be important in honey production, even though the flora surrounding apiaries is primarily native. Several authors (Horn and Aira, 1997; Montenegro et al., 2003; Ramírez and Montenegro, 2004, Forcone et al., 2005; Fagúndez and Caccavari, 2006; Montenegro and Fredes, 2008; Böke, 2013; Ciappini and Vitelleschi, 2013; Montenegro et al., 2013a, 2013b) have reported the presence of certain pollen types from diverse species considered weeds in monofloral honeys made from the nectar of native species, and monofloral honeys made from the nectar of weeds have even been reported. Many weed species are also pollen sources, as has been shown by several authors (Montenegro et al., 1992; Montenegro et al., 1997; Forcone et al., 2011; Chamorro-García et al., 2013), but in this work, we analyzed only nectar sources. The objective of this study was to determine which weed species are of melliferous importance in central Chile. Based on this information, we would recommend to beekeepers that they use these species to the maximum extent possible during the season when they flower in abundance and that they should not eliminate species that contribute significantly to nectar storage during droughts and during periods in which the flowering of native species is at a low level.

\section{Materials and methods}

A total of 92 honey samples from the 2011/2012 and 2012/2013 seasons were selected to determine the most important weeds used by Apis mellifera and those most preferred by the bees. The weed presence was determined in 20 counties in the O'Higgins region. The relative participation of individual weed species in the pollen fraction of each honey sample was determined using a melissopalynological test in accordance with Chilean regulation (NCh2981.Of2005; Ministerio de Agricultura. 2006) to evaluate the botanical origins of the pollen fraction. A total of $20 \mathrm{~g}$ of honey was taken from each sample, diluted in $20 \mathrm{~mL}$ of distilled water and manually homogenized. The mixture was centrifuged for $10 \mathrm{~min}$ at $3,000 \mathrm{rpm}$.

After centrifugation, the supernatants were discarded, and the pollen grains remaining in the pellet of each sample were homogenized with a stirrer. A total of $100 \mu \mathrm{L}$ of each sample was deposited on each of four microscope slides. The four preparations were observed under an optical microscope, and the pollen grains from each species were counted (Montenegro et al., 2003; Ramírez and Montenegro, 2004; Forcone et al., 2005; Fagúndez and Caccavari, 2006; Montenegro et al., 2013a). The pollen types that were identified and that corresponded to species that are considered weeds were classified according to their importance in Chilean crops, 
as specified by Matthei (1995), based on the classification system proposed by Holm (1979). This classification system consists of a scale ranging from 1 to 6 according to the damage or economic losses caused by the presence of a given weed in crops. This classification system also covers species that are harmful to humans and animals. Very serious weeds in the country, those that may cause a total loss if not eliminated from a crop, are placed in Category 1; species classified as a main weed, indicating that their presence causes considerable damage but not a complete loss of production, are placed in Category 2; species classified as common weeds, which are very widespread and require constant control efforts, are placed in Category 3; species that behave as weeds but whose importance as weeds is unknown are placed in Category 4; species that are identified as flora in Chile and are found occasionally in crops are placed in Category 5; and species that are identified as toxic because they contain toxic substances, e.g., alkaloids, phytotoxins or toxic minerals, are placed in Category 6.

After classification, the pollen grains from different weeds were then grouped according to the methodology described by Louveaux et al. (1970), in which each pollen type in a honey sample is categorized according to the percentage of the sample that is derived from that pollen type. The categories are as follows: very frequent $(\geq 45 \%$ of the total pollen grains counted), frequent (16-45\%), rare (3-15\%) and occasional $(<3 \%)$. Additionally, the frequency of appearance of the pollen grains of each weed was determined relative to the total number of honey samples examined.

\section{Results and discussion}

Of the 114 pollen types in the samples, 52 were identified at the species level, and 19 of these 52 pollen types were found to correspond to weeds. The remaining pollen types were identified at the genus level.
Five of the pollen types identified at the genus level were selected due to their importance as weeds and were considered along with the 19 weed species. In the weed taxa present in the honey samples, the families most frequently represented were Fabaceae (eight species and three genera), Brassicaceae (one species and two genera) and Asteraceae (two species). These families have also previously been reported to be the most frequently observed sources of pollen in honey samples (Valle et al., 2001; Forcone et al., 2005; Fagúndez and Caccavari, 2006; Böke, 2013; Ciappini and Vitelleschi, 2013). Overall, 74\% of the weeds used by Apis mellifera were European in origin, and $53 \%$ of the weeds had perennial life cycles (Table 1). It is interesting that 43 of the 92 honey samples analyzed were monofloral. A total of 29 of the monofloral honeys were derived from native species, e.g., Quillaja saponaria and Retanilla trinervia; 13 honey samples were derived from Galega officinalis, and one was derived from Medicago sativa.

At least one species categorized as a weed was found in $100 \%$ of the honey samples analyzed; however, nonspecific weed was present in all of the samples analyzed (92).

Galega officinalis was the most frequently observed weed, according to the classification system developed by Louveaux et al. (1970), as this weed appeared in more than $91 \%$ of the honey samples analyzed. Although the pollen grains of G. officinalis were found at varying frequencies, in $14 \%$ of the honey samples, the level of abundance of $G$. officinalis was greater than $45 \%$; such honey samples were classified as monofloral. The other monofloral honey samples were derived from $M$. sativa. Interestingly, both species are of European origin, are from the same family and have perennial life cycles. These similarities are not due to chance, and we may deduce that the bees' preference for these species may be associated with the morphologies of the flowers of these species, their life cycles, the availability of their flowers and the 
Table 1. Botanical classification of weeds found in the honey samples.

\begin{tabular}{|c|c|c|c|}
\hline Species & Family & Origin & Life cycle \\
\hline Galega officinalis $\mathrm{L}$. & Fabaceae & Europe & Perennial herb \\
\hline Medicago sativa $\mathrm{L}$. & Fabaceae & Euroasian & Perennial herb \\
\hline Trifolium repens $\mathrm{L}$. & Fabaceae & Europe & Perennial herb \\
\hline Medicago polymorpha $\mathrm{L}$. & Fabaceae & Europe & Annual herb \\
\hline Melilotus indicus (L.) All. & Fabaceae & Europe & Annual herb \\
\hline $\begin{array}{l}\text { Raphanus raphanistrum subsp. } \\
\text { sativus (L.) Domin }\end{array}$ & Brassicaceae & Europe & $\begin{array}{l}\text { Annual herb or } \\
\text { biannual }\end{array}$ \\
\hline Lotus pedunculatus Cav. & Fabaceae & Europe & Perennial herb \\
\hline Rubus ulmifolius Schott. & Rosaceae & Europe & Perennial herb \\
\hline Eschscholzia californica Chamb. & Papaveraceae & $\begin{array}{l}\text { California, } \\
\text { U.S.A. }\end{array}$ & Perennial herb \\
\hline Anthemis cotula $\mathrm{L}$. & Asteraceae & Europe & Annual herb \\
\hline Rumex acetosella $\mathrm{L}$. & Polygonaceae & Europe & Perennial herb \\
\hline $\begin{array}{l}\text { Acmispon subpinnatus (Lag.) D.D. } \\
\text { Sokoloff }\end{array}$ & Fabaceae & Chile & Annual herb \\
\hline Daucus carota $\mathrm{L}$. & Apiaceae & Europe & $\begin{array}{l}\text { Annual herb or } \\
\text { biannual }\end{array}$ \\
\hline Echium vulgare $\mathrm{L}$. & Boraginaceae & Europe & Biannual herb \\
\hline Trifolium pratense $\mathrm{L}$. & Fabaceae & Europe & Perennial herb \\
\hline Convolvulus arvensis $\mathrm{L}$. & Convolvulaceae & Europe & Perennial herb \\
\hline Coriaria ruscifolia $\mathrm{L} .{ }^{1}$ & Coriariaceae & South America & Shrub \\
\hline $\begin{array}{l}\text { Helenium aromaticum (Hook.) L.H. } \\
\text { Bailey }\end{array}$ & Asteraceae & Chile & Perennial herb \\
\hline Alnus glutinosa (L.) Gaertn. ${ }^{1}$ & Betulaceae & Europe & Tree \\
\hline Brassica sp. & Brassicaceae & & \\
\hline Sisymbrium sp. & Brassicaceae & & \\
\hline Trifolium sp. & Fabaceae & & \\
\hline Lotus sp. & Fabaceae & & \\
\hline Medicago sp. & Fabaceae & & \\
\hline
\end{tabular}

${ }^{1}$ According to Holm et al. (1979), these species are not considered weeds but have been included because they were present in the samples that were analyzed.

nutritional content (e.g., sugar) of the nectar in their flowers. The finding that fewer than $10 \%$ of the samples studied may be classified as nonnative monofloral is consistent with the results reported by Horn and Aira (1997), who identified only one monofloral honey, which was derived from Trifolium repens, in the Los Lagos region of southern Chile.

Another important species found in the analysis of pollen in the honey samples was Trifolium repens, which was detected in $92.4 \%$ of the samples analyzed, at a level of abundance of less than $15 \%$, relative to the pollens of other species in each sample.

As shown in Table 2, eight out of 19 weed species used as a nectar source by $A$. mellifera belonged to the Fabaceae family. Additionally, five weed species belonging to this family showed a frequency of occurrence greater than $30 \%$ in the honey samples. This preference may be explained by the fact that many species of this family offer nectar as a reward. The nectar is secreted by a nectary, which is generally located at the base of the staminal filaments, and it accumulates between the stamens and the pistil (Rodríguez - Riaño et al., 1999). 
Table 2. Pollen types corresponding to weeds identified in 92 honey samples analyzed according to their importance as weeds in Chile (Matthei, 1995) and their level of abundance and frequency of appearance (Louveaux et al., 1970).

\begin{tabular}{|c|c|c|c|c|c|c|}
\hline \multirow[b]{2}{*}{ Weed } & \multirow[b]{2}{*}{ Importance $^{2}$} & \multicolumn{4}{|c|}{ Level of abundance $^{1}$} & \multirow[b]{2}{*}{ Frequency $^{3}(\%)$} \\
\hline & & Very frequent & Frequent & Rare & Occasional & \\
\hline Galega officinalis & 1 and 6 & 13 & 29 & 31 & 11 & 91.30 \\
\hline Medicago sativa & 5 and 6 & 1 & 14 & 44 & 21 & 86.96 \\
\hline Trifolium repens & 5 and 6 & - & 7 & 38 & 40 & 92.39 \\
\hline Medicago polymorpha & 3 & - & 1 & 18 & 28 & 51.09 \\
\hline Melilotus indicus & 3 and 6 & - & 1 & 5 & 25 & 33.70 \\
\hline $\begin{array}{l}\text { Raphanus raphanistrum subsp. } \\
\text { sativus }\end{array}$ & 1 & - & 1 & 1 & 1 & 3.26 \\
\hline Lotus pedunculatus & 4 & - & - & 4 & 16 & 21.74 \\
\hline Rubus ulmifolius & 1 & - & - & 3 & 40 & 46.74 \\
\hline Eschscholzia californica & 3 and 6 & - & - & 3 & 21 & 26.09 \\
\hline Anthemis cotula & 1 & - & - & 2 & 5 & 7.61 \\
\hline Rumex acetosella & 1 and 6 & - & - & 1 & 8 & 9.78 \\
\hline Acmispon subpinnatus & 4 & - & - & 1 & 2 & 3.26 \\
\hline Daucus carota & 2 & - & - & 1 & 0 & 1.09 \\
\hline Echium vulgare & 1 & - & - & - & 10 & 10.87 \\
\hline Trifolium pratense & 5 & - & - & - & 6 & 6.52 \\
\hline Convolvulus arvensis & 1 & - & - & - & 3 & 3.26 \\
\hline Coriaria ruscifolia & 6 & - & - & - & 1 & 1.09 \\
\hline Helenium aromaticum & 3 & - & - & - & 1 & 1.09 \\
\hline Alnus glutinosa & 5 & - & - & - & 1 & 1.09 \\
\hline Brassica sp. & & - & 8 & 34 & 33 & 81.52 \\
\hline Sisymbrium sp. & & - & 1 & 1 & 4 & 6.52 \\
\hline Trifolium sp. & & - & - & - & 2 & 2.17 \\
\hline Lotus sp. & & - & - & - & 2 & 2.17 \\
\hline Medicago $s p$. & & - & - & - & 1 & 1.09 \\
\hline
\end{tabular}

${ }^{1}$ Number of samples according to abundance: very frequent ( $\geq 45 \%$ of the total pollen grains counted); frequent (16-45\%); rare $(3-15 \%)$ and occasional $(<3 \%)$.

${ }^{2}$ 1: very serious; 2 : main weed; 3: common weed; 4: weed; 5: flora; 6: toxic.

${ }^{3}$ Frequency: percentage of total samples that contain each type of pollen.

The abundance of weeds considered very serious and difficult to control, such as $R$. raphanistrum, $C$. arvensis and $E$. vulgare, was low in the honey samples; they appeared in fewer than $3 \%$ of the samples and were the source of only a small portion of the pollen in those samples, as well. This result implies that if these weed species are under control, they will generally not affect honey production. In contrast, other weeds that are considered very serious, such as $R$. ulmifolius, appeared a substantial proportion (40/92) of the honey samples analyzed, but the abundance of pollen from these species was lower than 3\% in such samples. Note that pollen grains of $R$. raphanistrum appeared in only one of the 92 honey samples analyzed, but it represented more than $30 \%$ of the pollen in that sample. This finding implies that $R$. raphanistrum pollen represents a valuable resource for A. mellifera and that it may contribute to a great extent, during its flowering period, to the feeding of the hive. 
Among the weed genera analyzed, the frequency of $81.5 \%$ observed for Brassica sp. is noteworthy in comparison to the other genera represented by several weed species. Although it was impossible to identify the pollen types from this genus at the species level, it is important to note that the high frequency with which this genus was observed in the samples could be due to the abundance of certain weeds, e.g., Brassica nigra and Brassica rapa, which both belong to this genus and would be strongly selected by $A$. mellifera because of the resources these plants offer. These weeds grow along roads and in abandoned sites in the region. In addition, the pollen from this genus could be derived from transgenic crops of Brassica napus, which is grown in the region for seed production. Although these seed crops occupy small areas, beekeeping products face a potential risk of contamination from transgenic pollen, as has been reported by several authors for other countries (Kwon and Kim, 2001; Rieger et al., 2001; Lu et al., 2002; Stewart Jr. et al., 2003; García and Altieri, 2005; Légère, 2005). Thus, it is important to monitor the presence of this species both in the field and in harvested honeys.

An analysis of the relative importance of different species must be conducted for species that are relatively less important as weeds (category 4: weed; 5: portion of flora). For example, Lotus pedunculatus, Acmispon subpinnatus and Trifolium pratense are species that appear occasionally and at a low frequency. Accordingly, their maintenance in the apiary environment can be recommended, as the selection of these species by melliferous bees may contribute to the diet diversity required by the hive.

The honey samples that were analyzed primarily represent sectors of the region that are relatively free from human intervention. In these areas, native flora is abundant relative to introduced species. However, bees showed a preference for weeds associated with crops and that grow along roads.

Although $31.5 \%$ of the honey samples analyzed in this study represented monofloral honeys derived from different native plant species in Chile, the weeds identified in these samples are significant as nectar sources for the hives and as companion species, because at least one weed was found in $100 \%$ of the honeys.

Influencing the floral composition of a sector in which melliferous bees forage has complex implications, in terms of resource management, because bees prefer specific resources (e.g., pollen, resins) based on the nutritional needs of the hive at any given moment.

\section{Acknowledgments}

This study was financed by the project "Transferencia Programa de Desarrollo de Biozonas Apícolas para la Valorización de su Cadena de Valor," Code ID 30126395 - 0, directed by Gloria Montenegro. 


\section{Resumen}

L. Grimau, M. Gómez, R. Figueroa, R. Pizarro, G. Núñez y G. Montenegro. 2014. Importancia de las malezas como flora melífera en Chile central. Cien. Inv. Agr. 41(3):387394. Estudios en Chile han demostrado la utilización de flora nativa por Apis mellifera L., sin embargo existen situaciones en que especies consideradas malezas tienen una alta participación en la composición floral de la miel. Para determinar qué malezas son las más importantes y preferidas por la abeja melífera, se analizaron 92 mieles provenientes de la Región del Libertador General Bernardo O'Higgins, a las cuales se les determinó su participación relativa en la fracción polínica. Para la evaluación del origen botánico se utilizó la Norma Chilena (NCh2981.Of2005) mediante análisis melisopalinológico. A las especies consideradas malezas se las clasificó según la importancia que poseen en los cultivos chilenos, de acuerdo a lo propuesto por Matthei (1995) usando la clasificación definida por Holm (1979). Estos autores categorizan las malezas desde muy seria, si tienen el potencial de causar pérdidas significativas del cultivo; a malezas con presencia ocasional, si solo son parte de la flora del país. Del total de morfos polínicos encontrados, se logró identificar 19 malezas a nivel de especie y cinco a nivel de género, las que varían entre muy frecuente, frecuente, raro y esporádicos, de acuerdo a la metodología para diagnosticar la frecuencia específica en mieles descrita por Louveaux et al. (1970). Del total, el 74\% de las malezas usadas por Apis mellifera fueron de origen europeo, y $53 \%$ corresponden a malezas con ciclo de vida perenne. Las familias más importantes corresponden a Fabaceae, Asteraceae y Brassicaceae. Se discute la importancia de especies consideradas malezas en la producción de miel chilena.

Palabras clave: Apis mellifera L., Chile, Fabaceae, malezas, zona central.

\section{References}

Beekman, M., and F. Ratnieks. 2000. Long-range foraging by the honey-bee, Apis mellifera L. Functional Ecology 14: 490 - 496.

Böke, G. 2013. Análisis florístico y melisopalinológico de la pradera alto andina del sector de Lagunillas, San José de Maipo, R.M. Available online at: http://www.tesis.uchile.cl/handle/2250/113616 (Website accessed: 18.12.2013).

Chamorro-García, F., D. León-Bonilla and G. NatesParra. Bee pollen as non-wood forest product in the eastern Andean highlands of Colombia. Colombia Forestal 16: 53 - 66.

Ciappini, M.C., and M.S. Vitelleschi. 2013. Palynological characteristics of eucaliptus (Eucalyptus sp.) and clover (Trifolium sp.) honeys from Argentinean Pampean Phytogeographic Province. Rev. FCA UNCUYO 45 (1): 247 - 258.

De Sá Otero, M.P., E. Díaz, and S. Armesto. 2004. Flower election by honeybee and floral morphology. Lazaroa 25: 113 - 123.
Duffield, G., R. Gibson, P. Gilhooly, A. Hesse, C. Inkley, F. Gilbert, and C. Barnard. 1993. Choice of flowers by foraging honey bees (Apis mellifera): possible morphological cues. Ecological Entomology 18: 191 - 197.

Fagúndez, G., and M. Caccavari. 2006. Pollen analysis of honeys from the central zone of the Argentine province of Entre Ríos. Grana 45: $305-320$.

Forcone, A., G. Ayestarán, A. Kutschker, and J. García. 2005. Palynological characterization of honeys from the Andean Patagonia (Chubut, Argentina). Grana 44: 202 - 208.

Forcone, A., P. Aloisi, S. Ruppel and M. Muñoz. 2011. Botanical composition and protein content of pollen collected by Apis mellifera L. in the north-west of Santa Cruz (Argentinean Patagonia). Grana 50: 30 - 39.

García, M., and M. Altieri. 2005. Transgenic crops: Implications for biodiversity and sustainable agriculture. Bulletin of Science Technology and Society 25: $335-353$. 
Groves, R. H. and di Castri, F. (eds.). 1991. Biogeography of mediterranean invasions. Cambridge University Press. Victoria, Australia. 485 pp.

Holm, L. J.V. Pancho, J.P. Herberger, D.L. 1979. A geographical atlas of world weeds. J. Wiley \& Sons. New York. 391 pp.

Horn, H., and M. Aira. 1997. Pollen analysis of honeys from the Los Lagos region of southern Chile. Grana 36: 160 - 168.

Kwon, Y., and D. Kim. 2001. Herbicide-resistant genetically-modified crop: its risks with an emphasis on gene flow. Weed Biology and Management $1: 42-52$.

Légère, A. 2005. Risks and consequences of gene flow from herbicide-resistant crops: canola (Brassica napus L.) as a case study. Pest Management Science 61: $292-300$.

Louveaux, J., A. Maurizio, and G. Vorwohl. 1970. Methods of melissopalynology. Bee World 51(3): $125-138$.

Lu, C., M. Kato, and F. Kakihara. 2002. Destiny of a transgene escape from Brassica napus into Brassica rapa. Theor. Appl. Genet. 105: 78 - 84.

Martin, N. 2004. Flower size preferences of the honeybee (Apis mellifera) foraging on Mimulus guttatus (Scrophulariaceae). Evolutionary Ecology Research 6: 777 - 782.

Matthei, O. 1995. Manual de las Malezas que crecen en Chile. Alfabeta Impresiones, Santiago, Chile. 545 pp.

Ministerio de Agricultura. 2006. Miel de abejas Denominación de Origen Botánico mediante Ensayo Melisopalinológico. NCh2981.Of2005 (2005). Declarada Norma Chilena Oficial de la República el 14 de diciembre de 2005. Decreto Exento $N^{\circ} 765$, Ministerio de Agricultura. Diario Oficial No38.358 del 9 de enero de 2006. Santiago, Chile.

Montenegro, G., M. Gómez and G. Ávila. 1992. Importancia relativa de especies cuyo polen es utilizado por Apis mellifera en el área de la Reserva Nacional Los Ruiles, VII región de Chile. Acta Botánica Malacitana 17: 167 - 174.

Montenegro, G., G. Ávila, D. Rougier and B. Timmermann. 1997. Pollen loads: source of carotenoids originating from the mediterranean plant communities of the central zone of Chile. Revista Chilena de Historia Natural 70: 91 - 99.

Montenegro, G., R. Pizarro, G. Ávila, R. Castro, C. Ríos, O. Muñoz, F. Bas, and M. Gómez. 2003. Origen botánico y propiedades químicas de las mieles de la Región Mediterránea Árida de Chile. Cien. Inv. Agr. 30: 161 - 174.

Montenegro, G., and C. Fredes. 2008. Relationship between the floral origin and the mineral profile in Chilean honeys. Gayana Bot. 65: 123 - 126.

Montenegro, G., S. Rodríguez, S. Vío, M. Gómez, R. Pizarro, A. Mujica, and X. Ortega. 2010. Investigación científica y tecnológica en productos apícolas. LOM Ediciones. Santiago, Chile. 240 pp.

Montenegro, G., J. Díaz - Forestier, C. Fredes, and S. Rodríguez. 2013a. Phenolic profiles of nectar and honey of Quillaja saponaria Mol. (Quillajaceae) as potential chemical markers. Biol. Res. 46: $177-182$.

Montenegro, G., F. Santander, C. Jara, G. Núñez, and C. Fredes. 2013b. Actividad antioxidante y antimicrobiana de mieles monoflorales de plantas nativas chilenas. Bol. Latinoam. Caribe Plant. Med. Aromat. 12: $257-268$.

Oerke, E. 2006. Crop losses to pests. The Journal of Agricultural Science 144: 31 - 43.

Ramírez, R., and G. Montenegro. 2004. Certificación del origen botánico de miel y polen corbicular pertenecientes a la comuna de Litueche, VI Región de Chile. Cien. Inv. Agr. 31: 197 - 211.

Rieger, M., T. Potter, C. Preston, and S. Powles. 2001. Hybridisation between Brassica napus L. and Raphanus raphanistrum L. under agronomic field conditions. Theor. Appl. Genet. 103: 555 - 560.

Rodríguez - Riaño, T., A. Ortega - Olivencia, and J. Devesa. 1999. Biología Floral en Fabaceae. Ruizia. Tomo 16. Monografías del Real Jardín Botánico de Madrid. CSIC. Madrid, España. p. 1 - 176.

Stewart Jr., C., M. Halfhill, and S. Warwick. 2003. Transgene introgression from genetically modified crops to their wild relatives. Nature 4: 806 -817 .

Valle, A., A. Andrada, E. Aramayo, L. Gallez, and S. Lamberto. 2001. Mieles de la región periserrana del Sistema de Ventania, Argentina. Invest. Agr. Prod. Veg. 16: 343 - 354. 